\title{
The Nexus Between External Debt And Economic Growth In Nigeria (1981 - 2009).
}

\author{
Atoyebi Kehinde Olusegun, Olohunlana Dapo Somod, \\ Sulaiman Adebayo Adeodu, Okafor Blessing Okechi. \\ Lagos State University, Ojo. Faculty of social science, Department of Economics. \\ University of Lagos, Department of Economics (M. Sc. Student). \\ Federal College of Education, Oyo Dept. of Business Education Faculty of Vocational \& Technical Education. \\ Lagos State University External System.
}

\begin{abstract}
The study seeks to determine the impact of external debt on Nigeria using annual data from 19812009. In our empirical analysis, we run ordinary least square test to verify the statistical significance of the variables used and Johansen cointegration to determine the order of integration among the variables. Empirical investigations revealed that the coefficient of external debt is statistically significant at $5 \%$ while other variables such as prime lending rate. Growth rate of GDP are not statistically significant.

Our cointegration result s revealed the existence of two cointegrating equations at $5 \%$ level of significance among Gross domestic product, external debt, PLR, GRGDP and GREXDS. The results show the existence of long-run relationship among the variables.
\end{abstract}

\section{Introduction}

External debt management refers to the establishment of the condition of issue and redemption of foreign loans. It involves the proceeds of administering the external public debt that is, providing for the payment of interest and arranging the refinancing of maturity bonds/debt. It involves a conscious and carefully planned schedule of the acquisition and retirement of loans contracted either for development purpose or to support the balance of payments. It makes use of estimates of foreign earnings, sources of exchange finance, sources of exchange finance, the project returns from the investment and the repayment schedule. It also includes an assessment of the country's capacity to service existing debts and a judgment on the desirability of contracting loans (CBN; 1996).

Nigeria's economic histories in the pre and post independence era are important in order to understand the magnitude of her economic problems and the measures in the recent past to combat the external debt crisis and achieve sustainable economy recovery and growth.

The nation's inability to meet all its debt service payments constitutes one of the serious obstacles to the inflow of external resources into the economy. The accumulation of debt service arrears, which is being compounded with penalty interest, has not permitted reduction in the debt stock, despite the fact that government has been servicing it external debt with US \$2.0 billion annually between 1991 and 1997. The reasons for this are varied. In some cases, debt problems have mainly stemmed from the efficient use and control of borrowed funds by debtor countries. In most countries, returns on investment had not even debt servicing cost. While in others an adequate policy framework for debt management has led to accumulation of external debts that have proved excessive for the countries debt servicing capacity. Many debtors have faced much higher than anticipated growth in debt payment relative to their growth in their exports of gods and services.

\section{Selected Existing Literature}

The ways in which a large external debt affects economic growth are deeply investigated by academic literature both theoretically and empirically. In traditional neo-classical models, the relation between debt and growth is positive, but this link is flawed by unrealistic assumption of perfect capital mobility.

Therefore, the general assumption is that a debt burden impinges on the rate of economic growth. This adverse effect works through different channels, related to stock of debt and to interest payment.

The flow effects of debt on economic performance are due to the so called" discourage public investment, since it soaks up resources from government budget and reduces the amount of money available for productive investment. This argument can be used also with respect to the debt-poverty nexus, since debt service payment shrinks total spending in poverty alleviation programs and in health and education services. Furthermore, the flow effect is not only related to public investment, since a squeeze in public investment is 
likely to reduce private investment as well, given that private agent need investment in basic infrastructure in order to undertake their investment projects (the degree of substitution between private and public investment is debated in literature, see Easterly and Schmidt-Hebbel 1999).

With regard to the consequences of a large stock of eternal debt one economic performance, economic literature has highlighted two different channels through which high debt impinge on economic growth.

Debt overhang: This means that whether the stock of debt is too large, the expected interest payments are a positive function of output. Thus, investments decrease, because their return will be taxed away by foreign creditors and the pace of economic growth will slow down. (Krugman, 1988 and Sachs, 1989).

Uncertainty: The presence of a large external debt makes the macroeconomic environment unstable; this affect is not only related to the variability of the main macroeconomics indicators (interest rates, exchange rates, inflation), but also to the policy and institutional framework. The consequences are not only related to scarce investment, but also to a limited access to international financial markets and to capital flight.

A study of foreign captain inflow and economic development in Nigeria by Osoghale and Amuruhiean (1987) found that oil exports and direct foreign investment (FDI) were positively related to the importation of consequently, real gross domestic product was found to be positively associated with oil found to be positively associated with some strategic sectors, such as manufacturing, transportation and communication, finance and insurance. These slow the dependency of these sectors on foreign debt in the Nigeria economy. The negative association of foreign debt with capital resources importation shows that foreign debt does not contribute to capacity expansion either in manufacturing, transport, communication, finance or insurance. However, when export is low, more loans are needed to import raw materials and consumables in order to maintain the existing level of production and employment in these sectors.

Many analysis beloved that the poor investment and growth performance of many highly indebted less developed countries since the onset of the debt crisis in 1982 can be attributed in part to the dis-incentive effect of their external debt burden. This phenomenon is usually referred to as "debt overhang" problem.

The debt overhang theory is based on the premise that if debt will exceed the service is likely to be an increasing function of the country's output level. Thus, some of the returns from investing in the domestic economy are effectively "taxed" away by existing foreign creditors and investment by domestic and new foreign investors is discouraged.

Under such circumstances, the debtor country shares only partially in any increase in output and exports because a fraction of that increase will be used to increased investment and repayment capacity and, as a result, the portion of debt outstanding becomes more likely to be repaid. When the effect is strong, the debtor is said to be on the "wrong side" of the Laffer curve. In this case, the debt Laffer curve refers to the relationship between the amount of debt repayment and the size of the debt. However, the idea of debt Latter curve also implies that there is a limit at which debt accumulation stimulates growth Elbadawi et al (1996). In reference to an aid Laffer curve, Lensik and white (1999) argue that there is a threshold at which more aid is detrimental to growth.

Also the liquidity constraint is referred to as "crowding out" effect by which the requirement to service debt reduces funds availability for investment and growth. A reduction in the current debt service should therefore lead to an increase in current investment for any given level of future indebtedness Cohen, (1993).

Other channels through which the need to service a large amount of external obligations can affect economic performance, include lack of access to international financial markets and the effects of the stock of debt on the general level of uncertainty in the economy Chaessens et al (1996).

The scope of debt overhang is much wider in that the effects of debts do not only affect investment in physical capital but any activity that involves incurring cost up-front for the sake of increased output in the future. Such activities include investment in human capital (in term of edcauiton and health) and in technology acquisition whose effect on growth may even be stronger overtime.

Empirical studies on external debt-economic growth relationship are numerous in the literature in both developed and developing countries. Theoretically, it is expected that the marginal product of capital should be higher than the world interest rate for developing countries. Then, such countries would benefit from external borrowing (Eaton 1993). However, external debt only helps to exploit the potentials of a country, it does not enhance it. Therefore, the only guideline is that the rate of return on spending should exceed the marginal cost of borrowing on the assumption that debt is paid (Indermit and Brian 2005).

Fischer (1993) while explaining the deficit-debt-growth relationship stated that larger budget surpluses are associated with more rapid growth through greater capital accumulation and greater productivity growth. He stated further that, high deficit may be consistent with low inflation for a while, but that a more detailed assessment of debt dynamics may be needed to see if the deficit is sustainable and therefore consistent with macroeconomic stability. 
Savvides (1992) while trying to measure the impact of debt overhang on the country's economic performance used a Two Stage Limited Dependent Variable model (2SLDV) procedure by cross section time series data from 43 Less Developing Countries (LDCs) encountering debt problem. The study concludes that debt overhang and decreasing foreign capital flows have significant negative effect on investment rates. In line with Savvides (1992), Deshpande (1997) attempted to explain the debt overhand hypothesis by an countries. The author argues that the adjustment measures, which are applied by severely indebted countries, have an impact on the indebted countries, since the investment crisis has typical implied a growth for highly indebted countries. Bauerfreund (1989) also show the external debt payments obligations reduced investment levels in Turkey, in 1985. He asserted that the debt overhand is as a result of both internal and external economic policies.

Cohen (1993) estimated an investment equation for a sample of 81 countries over tree sub periods using ordinary square method (OLS). The author shows that the level of debt does not explain the slowdown of investment in highly rescheduling developing countries.

Warner (1992) tried to measure the size of debt crisis effect on investment with Least Square estimation for 13 less developed countries over the period 1982-1989. He affirmed that the reasons behind the decline of investment in many heavily indebted countries are declining export prices, high world interest rates and sluggish growth in developed countries. Rockerbie (1994) criticized Warner (1992) of various shortcoming. Rockberie (1994) used O.L.S for each of the 13 countries over a sample period of 1965-1990 and the result affirm that the debt crisis of 1982 had significant effects in terms of dramatic slowdown of investment in less developed countries. Afxentious and Serieties (1996) in furtherance to Afxentious (1993) examined 55 countries facing debt service difficulties.

The study's objective was to find out the relationship between foreign borrowing and productivity over the period 1970-1990. The results show that during the period 1970-1980, the relationship between indebtedness and national productivity is not negative. They submitted that the developing countries used the foreign loans to absorb the shock from oil price increase as painless as possible. However, for the period 1980-1990 when the debt forgiveness and rescheduling started, the debt crisis and debt overhang affected some indebted countries.

Fosu (1996) tested the relationship between economic growth and external debt in sub Saharan African countries over the period 1970-1986 using O.L.S method. The study examined the direct and indirect effect of debt hypothesis. Using a debt-burden measure, the study reveals that direct effect of debt hypothesis shows that GDP is negatively influenced via a diminishing marginal productivity of capital. The study also finds that on the average a high debt country faces about one percent reduction in DGP growth annually. Fosu (1999) also employed an augmented production function to investigate the impact of external debt on economic growth in 1980-1990. The author tested whether external debt as negative effect on economic growth and the findings show that debt exhibit a negative coefficient.

Cuningham (1993) examined the association between debt burden and economic growth for 16 heavily indebted countries during the period 1971-1987. The study concludes that the growth of a nation's debt burden has a negative effect one economic growth during the period 1970-1979.

Smyth and Hsing (1995) tried to test the impact of federal governances' debt on economic growth and examine if the optimal debt ratio exists that will maximize growth. The debt/GDP ratio corresponding to the maximum GDP growth rate was found to be $38.4 \%$. The results show that during 1980s and early 1990s, federal debt has a differential role in economic growth. In the early 1980 s, debt ratio rose but it was below 38.4, thus debtfinancing stimulates economic growth.

Debt-economic growth nexus has also found significance among several other scholars. Essien and Onwioduokit (1998) examine the impact of foreign debt on economic growth and they found that the degree of responsiveness of growth to external finance in Nigeria is elastic. By implication government should only put in place appropriate debt management strategies to enhance economic growth. The debt burden of a country and the consequent debt service impose a constraint on the economy in terms of insufficient foreign exchange into finance importation of raw materials and capital goods needed for economic growth. Another serious constraint is found in debt overhand theory which states that the accumulated debt burden adversely affect the rate of private investment. The debt stock acts as tax on future income and production and discourages investment by the private sector.

Studies including Sach's (1986) have made a theoretical case for debt overhang effect by analysing the crowding out effect of debt on service payments. They posit that many highly indebted poor countries frequently divert foreign exchange resources to meet pressing debt service obligation of interest to policy makers presently is the effect of debt relief granted some African countries and as put by Burnside and Fanizza (2004), it differs from previous major debt relief initiatives in that it requires that budgetary resources saved from debt service be used for poverty reduction purposes. This view however need to be interpreted with caution as many countries in Africa have specific-country problems which may not allow the impact of the debt reduction be felt by the common man. For example in Nigeria, rather than having a positive feel of debt relief, the standard of living of 
an average Nigerian has worsen due to escalation of prices of essential commodities and growing food shortages.

In the findings of Iyoha (2000), he opines that a 75\% debt stock reduction would have raised the sub Saharan African countries for the period investment-GDP ratio by $8.6 \%$ and increased GDP by $7.8 \%$ and the debt /GDP ratio will fall by $65 \%$. No doubt, the debt reduction is expected to promote growth. In a study conducted by Chavin and Kraay (2005) on a sample of 62 low-income countries assessed the extent to which debt relief induces government to embark on social spending. They conclude that the marginal benefits of debt relief may no be sure in Africa, Latin American and Asia. Lora and Olivera (2006) test the crowding out effect of public debt on social services between 1985-2003 and find that the effect comes mostly from stock of debt and not debt service. They posit that loans from multilateral organization do not ameliorate the adverse consequences of debt on social expenditures. Thus, if Lora and Olivera's results hold for Africa, beneficiaries of debt relief should have increased their expenditure in the social (Dessy and Vencatachellum, 2007).

Evidence from (Dessy and Vencatachellum, 2007) study however show that if a government has a high discount factor, it will consume than invest once debt relief is granted. This is particularly true of most developing countries that have high marginal propensity to import.

These findings are consistent with Cooper and Sachs (1985) and Arslanalp and Henry (2004) who argue that the people faced by debt-relieved countries is lack of good institutions. Thus, if the status-quo remains the same, the new debt-relief initiative would not achieve their objectives to increase growth promoting expenditure in these countries. Similar studies that have found relationship between debt and growth include Cohen (1995), Bovensztem (1990), Elbadawi (1997) and Patillo et al. (2002, 2003). Few other studies did not find a significant effect of debt on growth and they include Savvides and Dijkstra and Hermes (2001).

On casualty analysis of external debt and growth, Afxentiou and Serletis (1996) used Granger casually test on a sample of 55 severely indebted countries and the results affirm that no casualty test exists between debt and income. The test shows that indebtedness is not a specific factor of per capital income growth. Hence, foreign resources can have a positive effect on economic development if resources are transferred into inputs since borrowing countries need to have these scarce resources. Amoateng and Amoaka (1996) investigated the relationship between external debt service and economic growth.

Chowdhury (1994) tried to resolve the Bullow and Rogof's (1990) proposition by finding the cause and effect relationship between external debt and economic slowdown in 7 Asian countries for the period 19701988. The results of Granger casualty test show that Bollow and Reogof (1990) proposition that external debt of developing countries are a symptom rather than a cause of economic slowdown was rejected. The results confirm a feedback or bi-directional relationship between debt and growth for Malaysia and Philippines. Karagol (2002) investigated the long run and short run relationship between external debt and economic growth for Turkey during 1956-1996 and the Granger casualty test result showed a unidirectional casualty from debt to economic growth.

\section{Origin Of Nigeria's External Debt}

In the 1950s Nigeria did not have the need to borrow much from abroad and so the outstanding external debt was small. At the same time, substantial earnings from export of agricultural produce coupled with grants from the United Kingdom made external borrowing unnecessary. Besides the growth for economic growth was limited and that was relatively little demand for investment goods since attaining independence in 1960, Nigeria has had cause at one time of the other to resort to external borrowing for developing purposes. The debt incurred before 1970 were mainly long-term loans form official sources such as the World Bank and the country's major Western trading partners. The debt did not exert much burden on the burden on the economy because interest charged on the loans were generally low, with grace period ranging from three to ten years and repayment period of between ten and forty years. (Omoruyi's 1997).

Moreover, the country had abundant revenue receipts from oil, especially during the oil boom in 1973-1976. However, a decline in oil receipt in 1977-1998 forced the country to raise the first jumbo loan of $\$ 1.0$ billion from International Capital market. This loans which had a period of eight years, including a grace of three years, was used to finance various long term project. Most of which did not yield nay revenue many years after repayment had commenced.

The recovery of the oil market in 1979 with oil price rising to an all time high to $\$ 40.00$ per barrel in $1980 / 1981$ led to the notion that the economy was buoyant. A consumption pattern that has favoured imported goods emerged, the import substitution industrialization strategy that was being adopted then also depend heavily on imported raw materials and machinery. However, the oil boom was short lived and when it collapsed in the early 1980s the economy immediately experienced considerable strains and stresses.

The production and consumption patterns that emerge in the era of oil boom could not be sustained in the face of declining foreign exchange earnings in the 1990s rather than addressing the problem of decline in foreign exchange revenue, both federal and state government of the second Republic breached Decree 30 of 
1978, which fixed the maximum external loans of the country at \$5 billion and embarked on imprudent and massive external borrowing, particularly from the International Capital Market to finance projects of doubtful viability. Thus pressure soon mounted on the various sectors of the economy resulting in huge imbalances in government finances, low external reserves and deficits in the balance of payment among others. Trade credits in respects of both insured and uninsured trade. Credits started accumulated and the problem so escalated (Anyanwu 1997).

\subsection{SOURCES OF NIGERIA'S EXTERNAL DEBT}

The sources of Nigeria's external debt include:
a) The Paris club of creditors
b) The London club of creditors
c) Multilateral creditors
d) Bilateral and private sector creditors
e) Promissory Note creditors

(a) Paris Club

Is a cartel of creditor countries that came into existence in 1956. It does have a fixed number of members. Current members of the Paris club are United Kingdom, Germany, France, Italy, Netherland, Spain, Switzerland, Japan, United States American, Australia, Belgium, Denmark, Finland, Ireland, Australia, Canada, Norway, and Russia.

(b) The London Club of Creditors

These creditors mainly grant uninsured and unguaranteed loans. Members of the club were crowned in 1976. They hold meetings concerning issues or problems of repayment.

(c) Multilateral Creditors

They are International Institutions. They include:

ADB-African Development Bank

IBRD-International bank for Reconstruction and Development

IFC-International Finance Corporation

IDA-International Development Association

ECC-European Economic Community

(d) Bilateral and Private Sector Creditors

These creditors usually grant loans for development purposes. Members are ECC (now European Union), The United States of America, The East European countries and Japan. White private sector creditors issue short-term loans and they are extended by commercial banks and individual foreign suppliers.

(e) Promissory Note Creditors

These creditors grant uninsured trade loans, resulting mainly from trade arrears. In 1982 and 1983, Nigeria had trade arrears, these arrears were financed by promissory notes.

\subsection{THE DEBT RELIEF FOR NIGERIA}

With progress made from the reduction of resources directed to debt servicing in 2004, the implementation of a home-gown economic reform programme, the National Economic Empowerment and Development Strategy (NEEDS), coupled with improvements in economic governance and the anti corruption drive of the Obasanjo administration, added incentives to the quest for debt relief for Nigeria among creditor nations. Also, it was argued that a debt relief was necessary if Nigeria was to achieve the objectives under NEEDS, as well as meet the Millennium Development Goals (MDGs) by 2015.

Consequently, on June 27 2005, the country secured a major breakthrough in her quest for debt relief, with the Paris club agreement to grant Nigeria an International Development Asstiance (IDA) which was supportive of the debt relief struggle. To give a practical effect to this, a delegation from the country met with the Paris club creditors on October 20, 2005 and a final agreement was reached to cancel 60\% (US\$ 18 billion) of Nigeria's debt with Paris club. The breakdown of the debt owed to Paris club was; Principal balance - US\$ $25,199,180.0$, Arrears -US\$5,684,634.53, Total - US\$30,883,814.53

The agreement involved a debt reduction under the Naples terms, on eligible debt after reduction. This was to be implemented in two phases, conditional on the implementation of a comprehensive economic reform programme under the Policy Support Instrument (PSI) as approved by the executive board of the International Monetary Fund (IMF) on October 17, 2005. The Naples terms are a more generous debt relief package reserved only for lower income countries d good performance on their reform programme.

In the fist phase, Nigeria undertook to pay arrears of US\$6.3 billion due on all categories of debts, while the Paris club creditors would grant a 33.0\%. The second phase would become due after the approval of the first review of the PSI by the Executive Board of the International Monetary Fund during the first half of 2006. Then, Nigeria would pay US\$ 6.1billion, the amount due under the post cut off date debt. The Paris club 
creditors grant a further cancellation of $34.0 \%$ on eligible debts and then buyback the remaining eligible debts. The execution of the fifth bilateral agreement with the Paris club creditors would facilitate the resumption of normal bilateral economic relationship with the member countries. The total amount to be paid under the debt relief to complete the exist strategy from Paris club debt overhand amounted to US\$ 12.4 billion.

According to Debt Management Office (DMO), Nigeria's total debt as at June ending 2006 stood at $\$ 16.9$ billion.

With the completion of the Paris club debt, the DMO stated that the priorities of the government would be to review and update earlier projections of the first workshop; ensure regular conduct of the DSA and build national capacity for Debt Strategy Analysis.

Nigeria's debt stock was reduced to a low percent of the country's GDP; achievable when the Paris club of creditor nation granted the country debt relief, after rigorous technical negotiation and tremendous level of diplomatic initiative geared towards gathering the support of the international community.

\section{Model Specification and Empirical Results}

We employ Ordinary Least Square (OLS) method of analysis to examine the relationship between real GDP and external debt and other variables in our study.

\section{Model Specification}

In order to empirically determine the impact of these variables on the capacity utilisation, the multiple regression equation is explicitly specified in functional form as follows:

GDP $=\mathrm{f}($ EXDS,PLR,GRGDP,GREXDS $)$

Where GDP $=$ Gross Domestic Products is dependent variable

\section{Definition of terms}

EXDS $=$ External Debt

PLR $=$

GRGDP $=$ GDP growth rate

GREXDS = External Debt growth rate

Equation 1 can be specifically expressed in explicit econometric form as follows:

$G D P=\alpha_{0}+\alpha_{1} E X D S+\alpha_{2} P L R+\alpha_{3} G R E X D S+\alpha_{4} G R G D P+U_{t}$

Where $U$ is stochastic or random error term (with usual properties of zero mean and non-serial correlation).

$\alpha_{1-} \alpha_{4}=$ Co-efficient of associated variables

$\alpha_{0} \quad=\quad$ Constant Intercept.

\section{Data Analysis and Findings}

\section{OLS Regression Results}

The Estimated Model for this research study is given below:

\section{$L N G D P=0.259683361052 * L N E X D S-0.023798833261 * P L R-0.000156516825192 * G R E X D S+$ $0.00120930125887 * G R G D P+9.73910158141$}

The Table below shows the analysis of the result of the data used in the study. The method of analysis employed is the Ordinary Least Square (OLS).

\begin{tabular}{crrrr}
\hline \hline Variable & Coefficient & Std. Error & t-Statistic & Prob. \\
\hline \hline LNEXDS & $0.259683^{* *}$ & 0.055599 & 4.670654 & 0.0001 \\
PLR & -0.023799 & 0.021259 & -1.119469 & 0.2740 \\
GREXDS & -0.000157 & 0.001053 & -0.148632 & 0.8831 \\
GRGDP & 0.001209 & 0.000868 & 1.393712 & 0.1762 \\
C & 9.739102 & 0.536069 & 18.16764 & 0.0000 \\
\hline \hline
\end{tabular}

$R^{2}=0.586345 ;$ Adj. $R^{2}=0.517403 ;$ F-statistics = 8.504855; Prob(F-statistic) $=0.000202 ;$ DWstat $=0.485017$; Source: Author's computation

Note: $* * *=$ significant at $1 \% ; * *=$ significant at $5 \%$ and $*=$ significant at $10 \%$

The result of estimation of the model summarized in the table above shows that there is a positive relationship between GDP, and EXDS and GRGDP. However, PLR is negatively related to real gross domestic product. A closer look at the result shows that EXDS is statistically significant at 5 percent. 
The R-squared which is the coefficient of determination, shows the percentage of variation in the dependent variable that was accounted for by variations in the explanatory variables. It measures the explanatory powers of the model. It is usually between zero and one. A close inspection of the table above indicates that the specified model has a fairly high coefficient of determination. This can be seen from R-squared of 59 per cent. The Rsquared reports that the variables can explain about 59 per cent of total variation in real gross domestic product the remaining 41 per cent variation in the real gross domestic product are not accounted for in the model or rather accounted for by other variables outside the model. The fitness of every regression result is based on its R-squared. The adjusted R-squared shows that asymptotically, the variables can explain approximately 52 per cent of total variation. The implication of this is that the model has goodness of fit.

F-statistics test the overall significance of the model under study. F-calculated is compared with Ftabulated where F- cal is greater than F-tab we reject the null hypothesis (Ho) and conclude that the variable is statistically significant in explaining the dependent variable. From the table, it shows that F-statistics is 8.504855; and Prob(F-statistic) is $\mathbf{0 . 0 0 0 2 0 2}$. We, therefore, reject null hypothesis and accept alternative hypothesis. This is because it is greater than the critical values of 2.57 and 3.79 at $1 \%$ and $5 \%$ respectively. Thus, it implies that the model under this study is statistically significantly different from zero. In other words, the explanatory variables jointly considered are significantly important in explaining variation in the dependent variable -real gross domestic product. Durbin - Watson Statistic is given as $\mathbf{0 . 4 8 5 0 1 7}$.

\section{Unit Root Test Result}

Literature has established that most time series variables are not stationary. Therefore, using nonstationary variables in the model might lead to spurious regression which cannot be used for precise prediction. (Gujarati, 2003). Hence, our first step is to examine the characteristics of the time series data used for estimation of the model to determine whether the variables have unit roots, that is, whether it is stationary and the order of integration. The Augmented Dickey-Fuller test is used for this purpose. A variable is considered stationary if the absolute ADF value is higher than any of the absolute Mackinnon values. The test is conducted with intercept term.

Table 2: Unit Root Test Summary Statistics (Augmented Dickey Fuller)

\begin{tabular}{|c|l|l|l|l|l|}
\hline \multirow{2}{*}{ Variables } & \multicolumn{2}{|c|}{ ADF Test Statistics } & \multicolumn{2}{c|}{ Critical Values (5\%) } & \multicolumn{1}{l|}{$\begin{array}{l}\text { Order of } \\
\text { Integration }\end{array}$} \\
\cline { 2 - 6 } & Level Difference & Level & - & \\
\hline GDP & -4.690472 & - & -2.963972 & - & \\
\hline EXDS & -5.308958 & - & -3.119910 & -2.967767 & \\
\hline PLR & -2.807130 & -7.828280 & -2.963972 & - & \\
\hline GRGDP & -5.542545 & - & -2.963972 & - & \\
\hline GREXDS & -4.925498 & - & -2.963972 & - & $\mathrm{I}(0)$ \\
\hline
\end{tabular}

Source: Author's computation

From the table above the results clearly shows that all the variables except PLR are stationary at levels. However, PLR is not stationary at level. This suggests the need to difference the series to obtain stationarity. At first difference, however this variable is integrated of the order of one.

\section{Cointegration test results}

Co-integration analysis is carried out to determine the existence of long-run relationship that exist between the dependent variable and its regressor. When one or all of the variables is/are non-stationary at level which means they have stochastic trend. Essentially, it is used to check if the independent variables can predict the dependent variable now (short-run) or in the future (long-run). The long run relationship among the variables were examined using Johasen (1991) conitegration framework. The cointegration result is presented in table 3 below.

Table 3: Cointegration Test

Unrestricted Cointegration Rank Test (Trace)

\begin{tabular}{|c|c|c|c|c|}
\hline $\begin{array}{l}\text { Hypothesized } \\
\text { No. of CE(s) }\end{array}$ & Eigenvalue & $\begin{array}{c}\text { Trace } \\
\text { Statistic }\end{array}$ & $\begin{array}{c}0.05 \\
\text { Critical Value }\end{array}$ & Prob.** \\
\hline None * & 0.999740 & 264.6371 & 69.81889 & 0.0000 \\
\hline At most $1 *$ & 0.912002 & 74.77622 & 47.85613 & 0.0000 \\
\hline At most 2 & 0.468517 & 18.87610 & 29.79707 & 0.5019 \\
\hline At most 3 & 0.162757 & 4.338187 & 15.49471 & 0.8744 \\
\hline At most 4 & 0.010915 & 0.252434 & 3.841466 & 0.6154 \\
\hline
\end{tabular}


Unrestricted Cointegration Rank Test (Maximum Eigenvalue)

\begin{tabular}{|c|c|c|c|c|}
\hline $\begin{array}{l}\text { Hypothesized } \\
\text { No. of CE(s) }\end{array}$ & Eigenvalue & $\begin{array}{c}\text { Max-Eigen } \\
\text { Statistic }\end{array}$ & $\begin{array}{c}0.05 \\
\text { Critical Value }\end{array}$ & Prob.** \\
\hline None * & 0.999740 & 189.8609 & 33.87687 & 0.0001 \\
\hline At most $1 *$ & 0.912002 & 55.90012 & 27.58434 & 0.0000 \\
\hline At most 2 & 0.468517 & 14.53791 & 21.13162 & 0.3226 \\
\hline At most 3 & 0.162757 & 4.085753 & 14.26460 & 0.8502 \\
\hline At most 4 & 0.010915 & 0.252434 & 3.841466 & 0.6154 \\
\hline
\end{tabular}

Note: * denotes rejection of the hypothesis at the 0.05 level

**MacKinnon-Haug-Michelis (1999) p-values

From the table above both the trace and the eigenvalue tests suggest that there are two cointegrating equations at the 5 per cent significance level among the gross domestic product, external debt, PLR, GRGDP and GREXDS. The results show that there is a long-run relationship existing among the variables.

\section{Granger causality test}

In order to examine the Granger causal relationships between the variables under examination we used the estimated model in the previous section. F statistic was used as a testing criterion. The results relating to the existence of Granger causal relationships between the variables are presented in table 4 below.

Table 4: Granger Causality Tests

\begin{tabular}{|c|c|c|c|}
\hline $\begin{array}{c}\text { Dependent } \\
\text { Variable }\end{array}$ & Testing Hypothesis & F1 & $\mathbf{F 2}$ \\
\hline \multirow{4}{*}{ GDP } & EXDS there is a unidirectional relationship(GDP $\Rightarrow$ EXDS) & 2.89557 & 2.22574 \\
\hline & PLR- there is no causality (GDP $\neq \mathrm{PLR}$ ) & 1.14801 & 0.09239 \\
\hline & GRGDP - there is a bidirectional relationship (RGDP $\Leftrightarrow$ GRGDP) & 4.67704 & 3.02857 \\
\hline & GREXDS - there is a unidirectional relationship(RGDP $\Rightarrow$ GREXDS) & 0.40236 & 8.09812 \\
\hline
\end{tabular}

Source: Author's computation

From table 4 above we can infer that: there is a unidirectional causal relationship between the gross domestic product and external debt with direction from gross domestic product. Also, there is unidirectional causal relationship between gross domestic product and GREXDS and direction from gross domestic product. Meanwhile, there is no causal relationship between the gross domestic product and PLR.

\section{1}

\section{Summary, Conclusion And Recommendations}

SUMMARY

This paper considered the impact of external debt on Nigeria economy, relevant data concerning the topic were gathered. The gathered data which was critically analysed was aimed at showing:

If external debt has an impact on Nigeria economy.

The extent to which external debt affects Nigeria economy through change in GDP.

Whether to accept null hypothesis $\left(\mathrm{H}_{0}\right)$ or alterna6tive hypothesis $\left(\mathrm{H}_{1)}\right.$, Using the standard T- test, $\mathrm{R}^{2}$ and standard error test.

The model which is in line with the specific objective, the GDP was expressed as the independent variables while (EXDS, PLR) were the independent variables.

The result show $\mathrm{R}^{2}$ to be 0.123 . The interpretation is that $12.3 \%$ of the changes in GDP in Nigeria are cause by EXDS and PLR. The remaining changes in GDP are explained by stochastic variable U.

The null hypothesis ( $\mathrm{H} 0)$ was subsequently accepted while (H1) was rejected based on the fact that $\mathrm{T}$ calculated $<$ T tabulated the value of $\mathrm{R}^{2}$ was relatively low $(12.3 \%)$ and $\mathrm{S}$.E $\left(\mathrm{b}_{1}\right)>\mathrm{b}_{1} / 2$.

The result shows that external debt does not help Nigeria economy to any way

\subsection{CONCLUSION}

This paper empirically examines the relationship between external debt and Nigeria economy using GDP. This is carried out using ordinary least square regression techniques, Johansen cointegration techniques and Granger Causality test method. 
It was discovered that the high and low level of external and internal factors. Worsen External debt issue in Nigeria. The external factor include: impact of world oil price shocks, rising real interest terms, declining term of trade and liberal landings policies of international commercial banks. The internal factor is attributed to successive administrations macro economic policy errors.

External debt eats gradually into an economy and starts mounting pressure on the various sector of the economy. Government should check its borrowing and ensure it is spending properly to help economic growth and ensure proper payment plan and strict adherence to it.

\subsection{RECOMMENDATIONS}

From the findings and conclusion above, this study provide the following recommendations for policy for policy makers, government agencies and appropriate authority for improvement. Suggestion to be considered includes the following:

Government should initiate and develop policies that will address the fundamental causes of external debt.

There should be political will from government to ensure proper use of borrowings to develop all sectors within the economy.

Proper debt payment plan should be formulated and strictly adhered to.

Government need to provide a model for public- private sector cooperation on develop human capital development to enhance development to strengthen the economy.

\section{References}

[1]. Adebisan Sulaimon O. (2005). External Debt, Private Investment and Economic Growth in Nigeria. Babcock Journal of Management and Social Science"

[2]. Afxentiou P.C (1993) GNP growth and foreign indebtedness in middle-income developing countries Int. Econs .J. 7(3) 81-92.

[3]. Afxentiou P.C and A. Serleties (1996a) Foreign indebtedness in low and middle-income developing countries Soc. Econ., 45 (1): 131-159.

[4]. Afxentiou P.C and A. Serleties (1996) Growth and foreign indebtedness in developing countries: An empirical study using long term cross-country data. J. Dev. Areas, 31(1)"25-40.

[5]. Ajayi S.I and Khan M.S. (2006). "External Debt and Capital Fight in Sub-Saharan Africa".

[6]. Ajayi S.I (1991). "Macroeconomic Approach to External Debt" The case of Nigeria. AERC paper 8, Initiative publishers, Nairobi".

[7]. Amoateng, K and A.B Amoaku, (1996). Economic growth, export and external debt causality: The case of African countries. Appl. Econ., 28:21-27.

[8]. Anaro B. (2006) "Nigeria's exit from the Paris club reduces Africa's debt burden by 10\%” Business day; Oct. 4 page 9.

[9]. Anyawu; J.C (1994) "An Analysis of External Debt Burden and Economic Development for the 1994 Conference of the Nigerian Economic Society".

[10]. Arslanalp, S. P.B. Henry, (2004). Helping the poor to help themselves: Debt relief or Aid? Working paper 10234, National Bureau of Economic Research, Cambridge, M.A.

[11]. Audu I. (2006). "The Impact of External Debt on Economic Growth and public Investment: The case of Nigeria".

[12]. Bauerfreund, O. (1989). External debt and economic growth. A computable general equilibrium case study of turkey, $1985-1986$. Unpublished Ph.D Thesis, Duke University, Dubia.

[13]. Bhatia; H.L (1984) "Public and External Finance" Viskas publishing, New Delhi.

[14]. Bovensztem, E., (1990): Debt overhang, debt reduction and investment: The case of Philippine. IMF Working paper.

[15]. Bullow, J. and R. Kenneth, (1990). Cleaning up third world debt without getting to the cleaners. J. Econ. Perspex 4 (1):31-42.

[16]. CBN (1994), CBN Brief. Special Edition. Research Department, Central Bank of Nigeria.

[17]. Chowdhury, K. (1994): A structural analysis of external debt and economic growth: Some evidence from selected countries in Asia and Pacific. Appl Econ., 26:1121-1131.

[18]. Cohen, D., (1993): Low investment and large LDC debt in the 1980s. Am Econ. Rev., 83 (3):437-449

[19]. Cummingham, R. T., (1993): The effect of debt burden on economic growth in heavily indebted nations J. Econ. Dev., 18(1):115126.

[20]. Desphande, A. (1997): The debt overhang and disincentive to invest. J. Dev. Econ., 52:169-187

[21]. Dessy, S.E and D. Vencatachellum (2007). Debt relief and social service expenditure: The African experience 1989-2003. Afr. Dev. Rev,. 19:200-216.

[22]. Dijkstra, G. and N. Hermes, (2001): The uncertainty of debt service payment and economic growth of highly indebted poor countries: Is there a case for debt relief? United Nations University Helsinki, (Unpublished Manuscript)

[23]. Easterly, William and Klaus Schmidt Hebbel, (1991) "The macroeconomics of public sector deficits' World Bank Country Economic Department Working Paper No.775.

[24]. Eaton, J. (1993): Sovereign Debt: A Primer. World Bank Econ. Rev. 7(3):137-172. 